\title{
Anandamide-induced cell death in primary neuronal cultures: role of calpain and caspase pathways
}

\author{
VA Movsesyan ${ }^{1}$, BA Stoica ${ }^{1}$, AG Yakovlev ${ }^{1}$, SM Knoblach ${ }^{1}$, \\ PM Lea IV ${ }^{1}$, I Cernak ${ }^{1}$, R Vink ${ }^{1}$ and AI Faden ${ }^{*, 1}$ \\ ${ }^{1}$ Department of Neuroscience, Georgetown University Medical Center, \\ Washington, DC, USA \\ * Corresponding author: Al Faden, Department of Neuroscience, Georgetown \\ University Medical Center, 3970 Reservoir Road NW, Research Building, Rm. \\ EP-12, Washington, DC 20057, USA Tel: 202-687-0492; Fax: 202-687-0617; \\ E-mail: fadena@georgetown.edu
}

Received 05.8.03; revised 30.10.03; accepted 02.3.04

Edited by $D$ Nicholson

\begin{abstract}
Anandamide (arachidonoylethanolamide or AEA) is an endocannabinoid that acts at vanilloid (VR1) as well as at cannabinoid (CB1/CB2) and NMDA receptors. Here, we show that $A E A$, in a dose-dependent manner, causes cell death in cultured rat cortical neurons and cerebellar granule cells. Inhibition of CB1, CB2, VR1 or NMDA receptors by selective antagonists did not reduce AEA neurotoxicity. Anandamideinduced neuronal cell loss was associated with increased intracellular $\mathrm{Ca}^{2+}$, nuclear condensation and fragmentation, decreases in mitochondrial membrane potential, translocation of cytochrome $c$, and upregulation of caspase-3-like activity. However, caspase-3, caspase-8 or caspase-9 inhibitors, or blockade of protein synthesis by cycloheximide did not alter anandamide-related cell death. Moreover, AEA caused cell death in caspase-3-deficient MCF-7 cell line and showed similar cytotoxic effects in caspase-9 dominantnegative, caspase-8 dominant-negative or mock-transfected SH-SY5Y neuroblastoma cells. Anandamide upregulated calpain activity in cortical neurons, as revealed by $\alpha$-spectrin cleavage, which was attenuated by the calpain inhibitor calpastatin. Calpain inhibition significantly limited anandamide-induced neuronal loss and associated cytochrome $c$ release. These data indicate that $A E A$ neurotoxicity appears not to be mediated by CB1, CB2, VR1 or NMDA receptors and suggest that calpain activation, rather than intrinsic or extrinsic caspase pathways, may play a critical role in anandamide-induced cell death.
\end{abstract}

Cell Death and Differentiation (2004) 11, 1121-1132.

doi:10.1038/sj.cdd. 4401442

Keywords: arachidonoylethanolamide; calpain; caspase; neuronal death; cortical neurons; cerebellar granule cells

Abbreviations: AEA, arachidonoylethanolamide; 2-AG, 2arachidonoyl-glycerol; CB1, cannabinoid receptor 1; CB2, cannabinoid receptor 2; CGC, cerebellar granule cells; $\mathrm{CHX}$, cycloheximide; FAAH, fatty acid amide hydrolase; $\mathrm{LDH}$, lactate dehydrogenase; NarPE, $\mathrm{N}$-arachidonoyl-phosphatidyl-ethanola- mine; NMDA, N-methyl-D-aspartate; PAGE, polyacrylamide gel electrophoresis; PMSF, phenylmethylsulfonyl fluoride; RCN, rat cortical neurons; VR1, vanilloid receptor 1

\section{Introduction}

Anandamide (arachidonoylethanolamide, AEA) belongs to a family of $\mathrm{N}$-acyl-ethanolamines that is formed in mammalian tissue (for review see Fride $^{1}$ and van der Stelt et al., ${ }^{2}$ ). Intracellular levels of AEA are regulated by a specific phospholipase D-like enzyme through hydrolysis of $\mathrm{N}$ arachidonoyl-phosphatidyl-ethanolamine (NarPE); ${ }^{3,4}$ by an uptake mechanism controlled by anandamide transporter; and through degradation regulated by a fatty acid amide hydrolase (FAAH) ${ }^{5-7}$ Anandamide was first isolated from brain and initially characterized as an endogenous ligand for cannabinoid receptors. Although agonist activity at both CB1 and $\mathrm{CB} 2$ receptors has been demonstrated, ${ }^{8,9}$ anandamide also acts as an agonist at a vanilloid (VR1) or capsaicin receptor. ${ }^{10-13}$ In addition, direct modulation of NMDA receptor activity by AEA has also been described. ${ }^{14}$ Anandamide appears to regulate a number of crucial cellular events, including cytosolic $\mathrm{Ca}^{2+}$ levels and cell proliferation. ${ }^{15-17}$

Endogenous cannabinoids, such as 2-arachidonoyl-glycerol (2-AG), are generally believed to play a neuroprotective role through actions at $\mathrm{CB}$ receptors, and anandamide has also been reported to provide neuroprotection through activation of CB receptors. ${ }^{4,18-21}$ However, in human neuroblastoma CHP100 and lymphoma U937 cell lines, anandamide induces apoptotic cell death through actions at VR1 receptors, leading to caspase activation. ${ }^{17}$

In the present studies, we show that anandamide induces dose-dependent cell death in both rat cortical neuronal and cerebellar granule cells. Such cell death is morphologically consistent with apoptosis and associated with changes in mitochondrial membrane potential, translocation of cytochrome $c$, activation of caspase-3, and increased levels of intracellular $\mathrm{Ca}^{2+}$. Administration of anandamide also upregulates calpain activity and treatment with calpain inhibitors significantly reduced cell death. In contrast, treatment with caspase inhibitors, cannabinoid or vanilloid receptor antagonists, or an NMDA antagonist does not provide protection against anandamide-induced neuronal cell death.

\section{Results}

Anandamide induces cell death in rat cortical neuronal and cerebellar granule cells cultures

Administration of anandamide to rat cortical neuronal cultures ( $R C N)$ caused cell death in a dose-dependent manner. The neurotoxic effects of anandamide were observed beginning at a $25 \mu \mathrm{M}$ concentration showing an almost two-fold increase in lactate dehydrogenase (LDH) release (Figure 1a). Application 

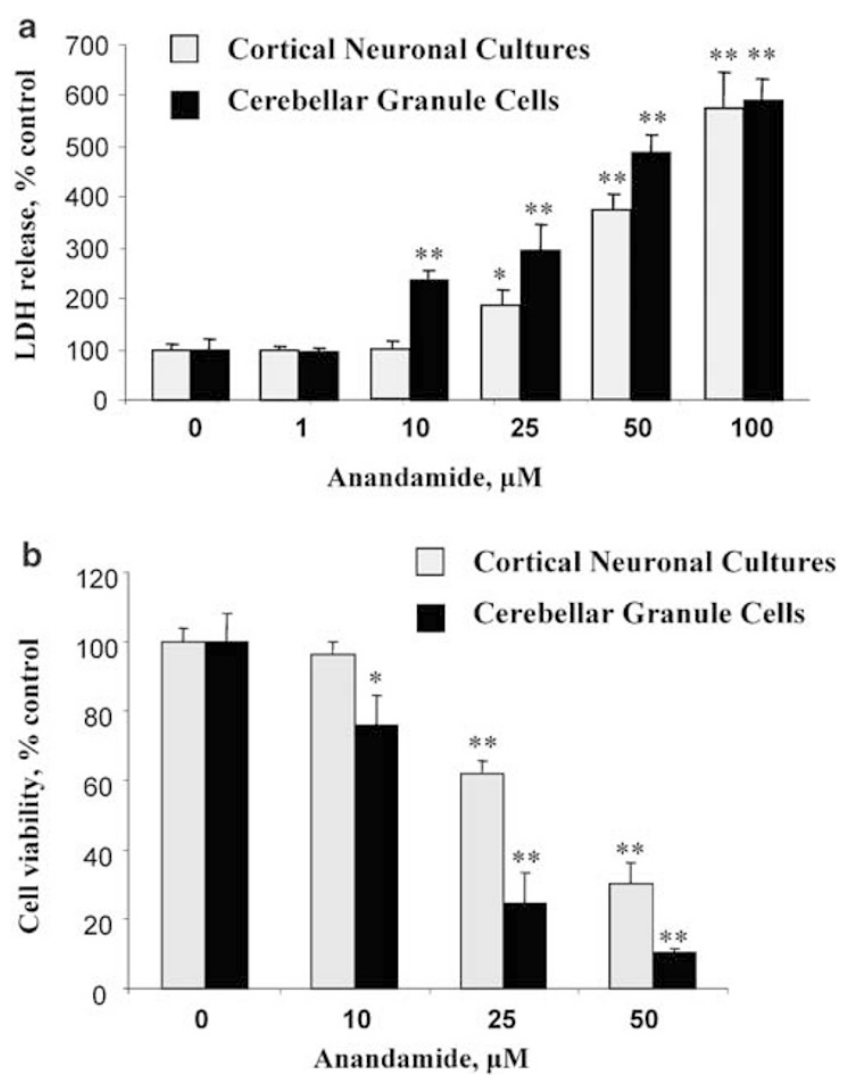

Figure 1 Anandamide induced dose-dependent cell death in cultured rat cortical neurons and cerebellar granule cells. Rat cortical neurons or cerebellar granule cells were treated with the indicated concentrations of anandamide. Cell viability was measured after $24 \mathrm{~h}$ of treatment by the LDH release assay (a) or calcein AM method (b). Each point represents the mean \pm S.D. of eight wells. The data are representative of $3-5$ separate experiments. ${ }^{*} P<0.05$ and ${ }^{* \star} P<0.01$ versus untreated controls compared by ANOVA, followed by Dunnett's test

of anandamide at concentrations of $10 \mu \mathrm{M}$ and lower had no effect on RCN viability. Similar results were obtained using a calcein AM cell viability assay (Figure 1b). Anandamide also caused cell death in cerebellar granule cell cultures. In this model, anandamide-induced cell death was evident at doses of $10 \mu \mathrm{M}$ and higher, while application of anandamide in concentrations equal or lesser than $1 \mu \mathrm{M}$ was without effect on cell survival, as measured by LDH release (Figure 1a). Again, similar results were observed using a calcein AM-based cell viability test (Figure $1 \mathrm{~b}$ ).

\section{Inhibition of cannabinoid, vanilloid or NMDA receptors by selective antagonists does not reduce anandamide-induced cell death in rat cortical neuronal cultures}

As shown in Table 1, no protection from anandamide-induced cell death was observed in cultures pretreated with VR1 antagonists capsazepine, isovelleral or ruthenium red (Table 1). These compounds have been previously shown to be effective VR1 antagonists in the dose range used. ${ }^{22-24}$ At $10 \mu \mathrm{M}$ dose capsazepine and isovelleral even exacerbated the injury. Similarly, the CB1 antagonist $A M 251^{25}$ had no protective effect in cultures given anandamide, while the CB2 antagonist $\mathrm{AM} 630^{26}$ at $1 \mu \mathrm{M}$ concentration exacerbated anandamide neurotoxicity, as measured by $\mathrm{LDH}$ release assay after $24 \mathrm{~h}$ of treatment. Application of the NMDA receptor antagonist $\mathrm{MK} 801^{27}$ at a dose of $10 \mu \mathrm{M}$ did not alter anandamide-induced cell death in RCN (Table 1).

\section{The metabolically stable anandamide analog meth- anandamide causes cell death in neuronal cultures; FAAH inhibition does not decrease anandamide-induced neuronal loss}

To test whether the effects of anandamide in neuronal cultures could be caused by the products of its degradation, we performed experiments in which anandamide was replaced with meth-anandamide, a nondegradable form of the compound, or when anandamide was administered to the cells in the presence of the FAAH inhibitor, phenylmethylsulfonyl fluoride (PMSF). ${ }^{28,29}$ As shown in Figure $2 a$, methanadamide also induced cell death in primary neuronal cultures, albeit at somewhat higher concentrations than required for anandamide. Significant decreases of cell viability were observed in meth-anandamide-treated cells at concentrations of 25 and $50 \mu \mathrm{M}$ in CGC and $\mathrm{RCN}$ cultures, respectively. Co-application of PMSF did not alter anandamide-induced cell death in cortical neuronal cultures at a dose of $0.1 \mu \mathrm{M}$, but exacerbated cell loss at $1 \mu \mathrm{M}$ (Figure $2 \mathrm{~b}$ ).

Table 1 Treatment with cannabinoid, vanilloid or NMDA receptor antagonists does not provide protection against anandamide-induced cell death in rat cortical neuronal cultures

\begin{tabular}{llc}
\hline Antagonist & Targeted receptor & Anandamide-induced LDH release, \% \\
\hline Capsazepine & VR1 & $113.5 \pm 9.9$ \\
Isovelleral & VR1 & $125.5 \pm 5.5^{\star}$ \\
Ruthenium Red & VR1 & $130.3 \pm 11.6^{\star}$ \\
AM251 & CB1 & $98.7 \pm 4.2$ \\
& & $104.7 \pm 5.6$ \\
AM630 & CB2 & $129.1 \pm 23.5$ \\
& & $118.6 \pm 17.6$ \\
MK801 & NMDAR & $161.8 \pm 15.1^{\star}$
\end{tabular}

Cell viability was measured by $\mathrm{LDH}$ release $24 \mathrm{~h}$ after incubation with $25 \mu \mathrm{M}$ anandamide with or without 30 min pretreatment with indicated concentrations of the antagonists. Data indicate LDH release as a percentage of that in cultures treated with anandamide alone $\pm S$.D.; $n=8-16$ cultures per condition. ${ }^{\star} P<0.05$, versus cultures received anandamide alone compared by ANOVA, followed by Dunnett's test. The results are representative of 3-5 separate experiments. 


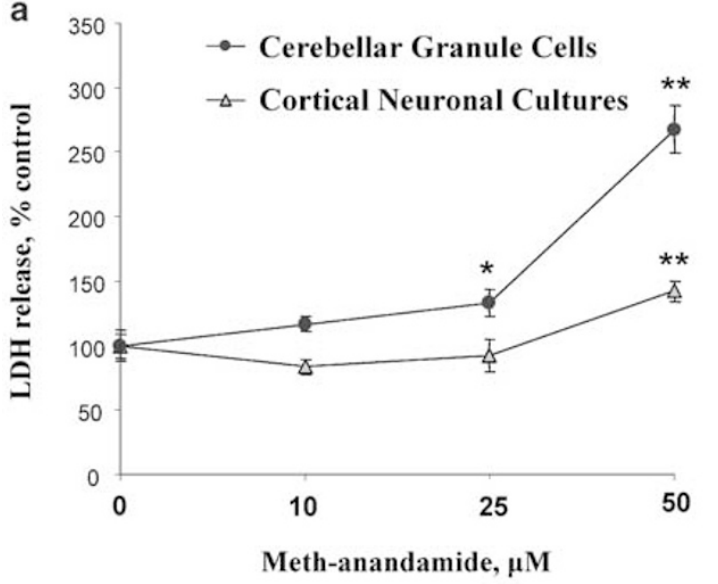

Cortical Neuronal Cultures

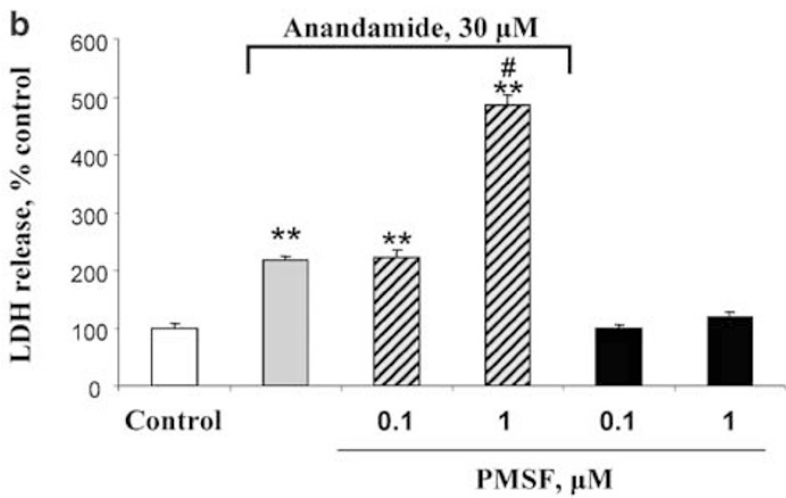

Figure 2 Meth-anandamide induced cell death in cultured rat cortical neurons and cerebellar granule cells. Rat cortical neurons or cerebellar granule cells were treated with the indicated concentrations of meth-anandamide. Cell death was measured after $24 \mathrm{~h}$ of treatment by the LDH release assay (a). Coadministration of anandamide with phenylmethylsulfonyl fluoride (PMSF) did not reduce, but rather exacerbated the neurotoxic effect of anandamide. Indicated concentrations of PMSF were added to rat cortical neurons with or without $30 \mu \mathrm{M}$ of anandamide, and cell death was measured after $24 \mathrm{~h}$ of treatment by LDH release assay (b). Each point reflects the mean \pm S.D. of eight wells. The data are representative of three separate experiments. ${ }^{*} P<0.05$ and ${ }^{* *} P<0.01$ versus untreated controls, $\# P<0.01$ versus cultures treated with anandamide alone compared by ANOVA, followed by the Dunnett's test

\section{Anandamide increases the number of cells with apoptotic morphology and causes caspase-3 activation in cortical neuronal cultures}

To examine whether anandamide-induced neuronal cell death was apoptotic, we evaluated characteristic features of apoptosis, such as nuclear condensation and fragmentation, as well as changes of active caspase- 3 protein levels and caspase-3-like enzymatic activity in anandamide-treated cells. Morphological evaluation of cortical neuronal cultures using Hoechst 33258 staining and fluorescent microscopy revealed a marked increase in the number of cells with nuclear condensation and fragmentation after $24 \mathrm{~h}$ of treatment with $25 \mu \mathrm{M}$ anandamide, as compared to control cultures (Figure $3 a, b)$. Immunoblot analysis of cytosolic protein extracts from cortical neuronal cells, incubated for different time periods with $25 \mu \mathrm{M}$ anandamide, showed a significant increase in

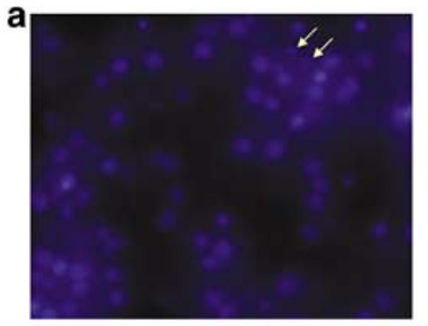

Control

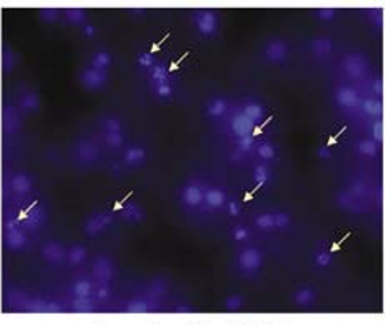

Anandamide (24 h) b

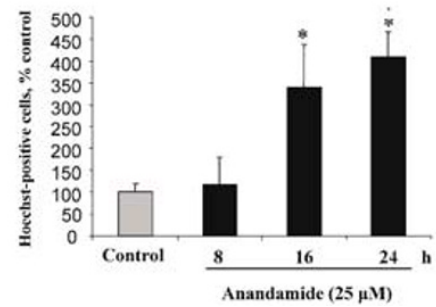

Figure 3 Treatment with anandamide significantly increased the number of cells with apoptotic morphology in rat cortical neuronal cultures. Cultures were treated with $25 \mu \mathrm{M}$ anandamide and after indicated periods of time, cells were stained by Hoechst 33258 and examined using fluorescent microscopy. Representative images of control and anandamide-treated cells (a). Hoechst 33258 staining revealed many condensed, fragmented, brightly stained nuclei after anandamide treatment, which is suggestive of apoptosis (a). Number of apoptotic cells was assessed using Hoechst 33258 staining and fluorescent microscopy (b). Histograms indicate the percentage of cells with apoptotic morphology as compared with untreated controls \pm S.D.; $n=300-400$ cells per condition. ${ }^{\star} P<0.01$ versus untreated controls compared by ANOVA, followed by Dunnett's test

active caspase- 3 protein levels after 16 and $24 \mathrm{~h}$ of treatment (Figure 4a). Caspase-3-like activity was also examined in cytosolic protein extracts from cortical neuronal cells treated with $25 \mu \mathrm{M}$ anandamide for $24 \mathrm{~h}$, and compared to that in sister control cultures. The fluorometric assay, using DEVDAMC as a substrate, showed an approximate four-fold increase in the caspase-3-like activity in anandamide-treated cells (Figure $4 \mathrm{~b}$ ). Parallel experiments where anandamideinduced cell death was measured using LDH assay revealed that significant reduction in cell viability occurred before caspase activation. Thus, levels of LDH release in cells treated with $25 \mu \mathrm{M}$ of anandamide for 4 and $8 \mathrm{~h}$ were $138.63 \pm 18.2$ and $149 \pm 16.8$, respectively, as compared to control cultures.

\section{Selective caspase inhibition or blockade of protein synthesis does not attenuate anandamide-induced neuronal loss}

Because anandamide caused cell death associated with caspase-3 activation, we examined whether caspase inhibitors could modify anandamide-induced neuronal loss. Surprisingly, pretreatment with the caspase inhibitors $z-$ DEVD-fmk, z-LEHD-fmk, or z-IETD-fmk had no effect on cell death induced in cortical neuronal cultures by treatment with $30 \mu \mathrm{M}$ anandamide, as assessed by LDH release at $24 \mathrm{~h}$ (Figure 5a). Although none of these antagonists are highly selective, they are believed to have some selectivity to 

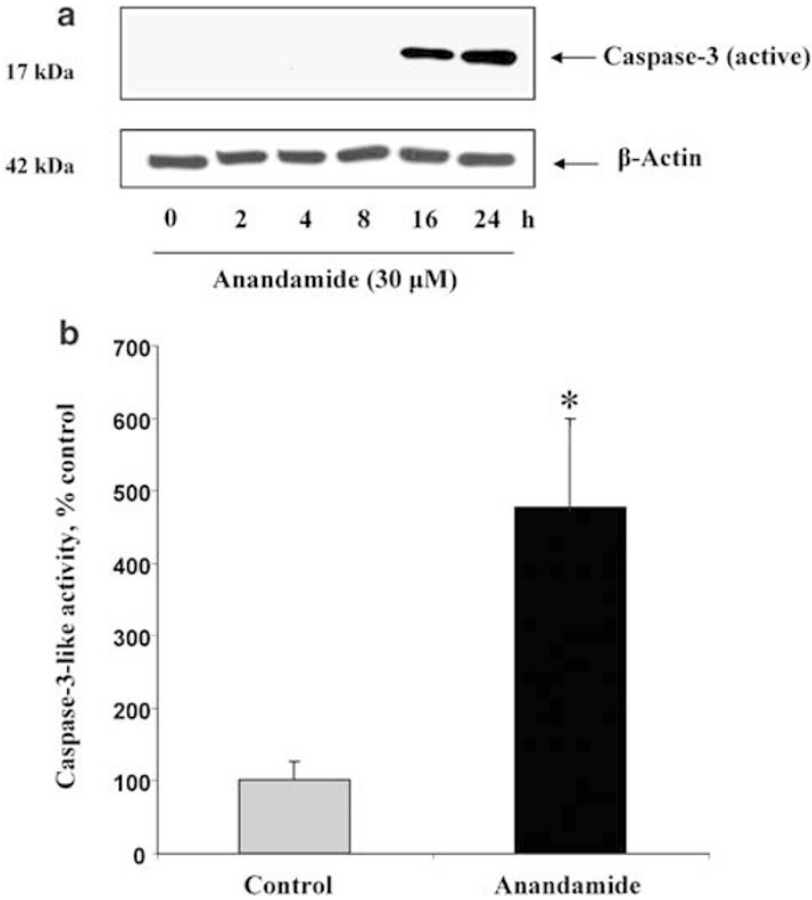

Figure 4 Treatment with anandamide significantly increased active caspase-3 protein levels and upregulates caspase-3-like activity in rat cortical neuronal cells. Cultures were treated with $30 \mu \mathrm{M}$ anandamide; after indicated time periods, cells were harvested and subjected to immunoblot analysis as described in Materials and Methods. $\beta$-Actin was used as an internal control (a). After $24 \mathrm{~h}$ of treatment with anandamide, caspase-3-like activity was measured fluorometrically as described in Materials and Methods (b). Histograms represent caspase-3-like activity as a percentage of the activity in control cells. ${ }^{*} P<0.01$ versus untreated controls compared by Student's two-tailed $t$-test

caspase-3, -9 and -8, respectively; at the concentrations used, these inhibitors have been shown to attenuate caspasemediated cell death. ${ }^{30,31}$ Notably, pretreatment with cycloheximide $(\mathrm{CHX})$, an inhibitor of protein synthesis, also did not decrease anandamide-induced cell death in the cultures. In contrast, the same dose of $\mathrm{CHX}$ was protective against etoposide-induced cell death (Figure $5 b$ ), a well-established model of caspase-mediated neuronal apoptosis. ${ }^{32}$

\section{Anandamide induces cell death in caspase-9 and -8 dominant-negative SH-SY5Y cells and caspase-3-deficient MCF-7 cells}

Because peptide caspase inhibitors used in our experiments are known to have only limited specificity, ${ }^{33}$ we also utilized dominant-negative caspase- 9 and -8 SH-SY5Y neuroblastoma cells stably transfected with mutant caspase- 9 and -8 constructs (see Materials and Methods). We further examined the effect of anandamide on cell viability in caspase- 9 and -8 dominant-negative $\mathrm{SH}-\mathrm{SY} 5 \mathrm{Y}$ cells in comparison to that for cells transfected with the empty vector (pcDNA3). As shown in Table 2, anandamide induced cell death in SH-SY5Y cells in a dose-dependent manner, as measured by LDH assay after $24 \mathrm{~h}$ of treatment. However, cell death caused by anandamide was not significantly reduced in caspase-8 or -9 dominantnegative SH-SY5Y cells, as compared to SH-SY5Y cells

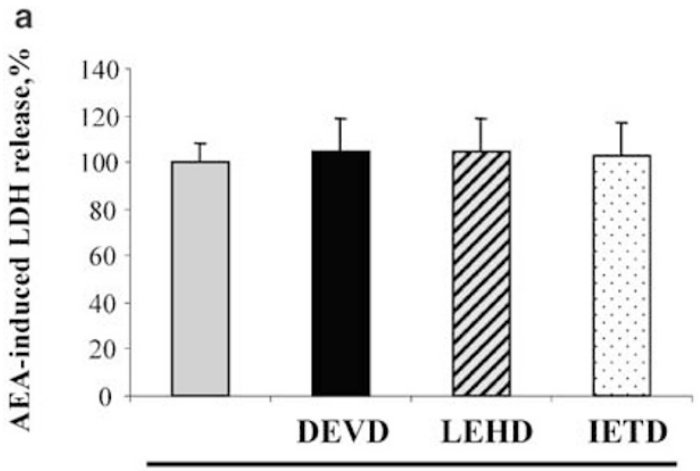

Anandamide $(30 \mu \mathrm{M})$

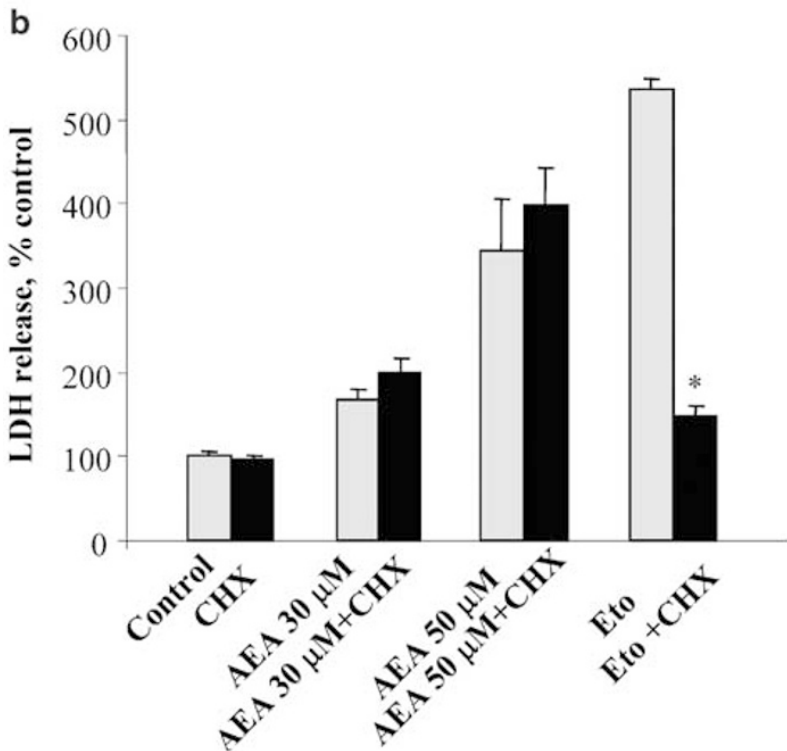

Figure 5 Pretreatment with the caspase-3 inhibitor z-DEVD-fmk, the caspase9 inhibitor z-LEHD-fmk, the caspase-8 inhibitor z-IETD-fmk, or protein synthesis inhibitor cycloheximide did not reduce anandamide-induced cell death in rat cortical neuronal cultures. In contrast, cycloheximide treatment blocked etoposide-induced cell death. Cell death was measured by LDH release assay after $24 \mathrm{~h}$ of incubation with $30 \mu \mathrm{M}$ anandamide with or without $1 \mathrm{~h}$ pretreatment with selective caspase inhibitors (each at $150 \mu \mathrm{M})(\mathrm{a})$ or after $2 \mathrm{~h}$ pretreatment with $10 \mu \mathrm{M}$ cycloheximide (CHX) followed by administration of indicated concentrations of anandamide (AEA) or $50 \mu \mathrm{M}$ etoposide (Eto) (b). The data are representative of $3-5$ separate experiments. Histograms indicate LDH release as percentage of controls \pm S.D.; $n=8$ cultures per condition; ${ }^{*} P<0.01$ versus etoposide-injured cells compared by ANOVA, followed by the Dunnett's test

transfected with empty vector (Table 2). In addition, effects of anandamide on cell viability were tested in MCF-7 human breast carcinoma cells that lack expression of caspase- 3 as a result of a deletion in the caspase- 3 gene..$^{34,35}$ In this system, anandamide was able to induce significant cytotoxicity at 20 and $50 \mu \mathrm{M}$ concentrations (Table 2).

\section{Anandamide stimulates calpain activation and calpain inhibitors provide protection against anandamide-induced cell death}

In parallel studies, we have recently found that intracerebroventricular (icv) administration of anandamide in rats causes 
Table 2 Treatment with anandamide induces cell death in caspase-8 dominant-negative (C8-/-), caspase-9 dominant-negative (C9-/-), and mock-transfected (EV) SH-SY5Y cells, as well as in caspase-3-deficient MCF-7 cells

\begin{tabular}{lccc}
\hline & & \multicolumn{2}{c}{ LDH release, \% control } \\
\cline { 2 - 4 } Anandamide $(\mu \mathrm{M})$ & SH-SY5Y (EV) & SH-SY5Y(C8-I-) & SH-SY5Y(C9-I-) \\
\hline 10 & $100 \pm 4.6$ & $100.2 \pm 2.4$ & $104.9 \pm 12.3$ \\
20 & $116.9 \pm 14.7$ & $107.8 \pm 5.4$ & $117.3 \pm 10.7$ \\
50 & $282.6 \pm 36.4^{*}$ & $254.6 \pm 10.7^{*}$ & $354.2 \pm 42.2^{*}$ \\
100 & $313.2 \pm 21.7^{*}$ & $299.9 \pm 13.3^{*}$ & $382.4^{*} 19.5^{*}$ \\
\end{tabular}

Cultures were treated with indicated concentrations of anandamide and $24 \mathrm{~h}$ after cell death was measured by LDH release assay. Data indicate LDH release as a percentage of untreated controls \pm S.D.; $n=8-16$ cultures per condition. ${ }^{*} P<0.01$ versus untreated control cells compared by ANOVA, followed by Dunnett's test.

activation of calpain in the brain and associated pathological changes (I Cernak et al., unpublished observation). Calpain has long been implicated in many models of cell death, both in vivo and in vitro. ${ }^{36-40}$ Cleavage of $\alpha$ ll-spectrin leading to formation of $150 / 145 \mathrm{kDa}$ fragments is a well-recognized marker for the calpain-generated protein breakdown. ${ }^{36,41} \mathrm{We}$ utilized immunoblot analysis of cleaved $\alpha$ ll-spectrin protein to examine anandamide-induced alterations in calpain activity. As shown in Figure 6a, treatment with anandamide caused significant increase in $145 \mathrm{kDa}$ fragment of cleaved allspectrin in cortical neuronal cells, as compared to intact cultures. Moreover, anandamide-induced $\alpha$ ll-spectrin cleavage was almost entirely blocked by coadministration of $25 \mu \mathrm{M}$ calpastatin, a calpain inhibitor (Figure 6b). It should be noted that levels of $120 \mathrm{KDa} \alpha \mathrm{ll}$-spectrin fragment, known to be generated by caspase-3-induced cleavage, ${ }^{42}$ remained unchanged until $24 \mathrm{~h}$ of treatment with anandamide (Figure 6a), when caspase-3 activity was also detected by immunoblot or fluorometric assay (Figure 4).

To explore a possible involvement of calpain-regulated pathway/s in anandamide-induced neuronal death, we also examined effects of various calpain inhibitors on survival of anandamide-treated cortical neuronal cultures. Pretreatment with cell-permeable calpain inhibitor calpastatin markedly enhanced viability of cortical neurons exposed to anandamide, as shown by calcein AM assay (Figure 7a). Similar results were obtained by measurements of $\mathrm{LDH}$ release (data not shown). It should be noted that application of the same dose $(25 \mu \mathrm{M})$ of this calpain inhibitor blocked $\alpha$ ll-spectrin cleavage in anandamide-treated cortical neuronal cultures (Figure 6b). Administration of another cell-permeable calpain inhibitor, calpeptin, also caused significant protection against anandamide-induced cell death in neuronal cultures (Figure $7 b, c)$. Notably, calpeptin markedly reduced anandamide toxicity at 4,8 , and $24 \mathrm{~h}$, whereas the caspase-3 inhibitor zDEVD-fmk did not provide protection, as measured by LDH release assay (Figure $7 \mathrm{c}$ ). Treatment with calpastatin also provided significant protection against anandamide-induced cell death in SH-SY5Y and MCF-7 cells, as revealed by calcein AM assay (Figure 7d,e).

\section{Intracellular $\mathrm{Ca}^{2+}$ levels are increased in anandamide-treated cortical neurons}

Given that upregulation of intracellular $\mathrm{Ca}^{2+}$ is known to be crucial for calpain activation (especially for $\mathrm{m}$-calpain) ${ }^{43}$ and is
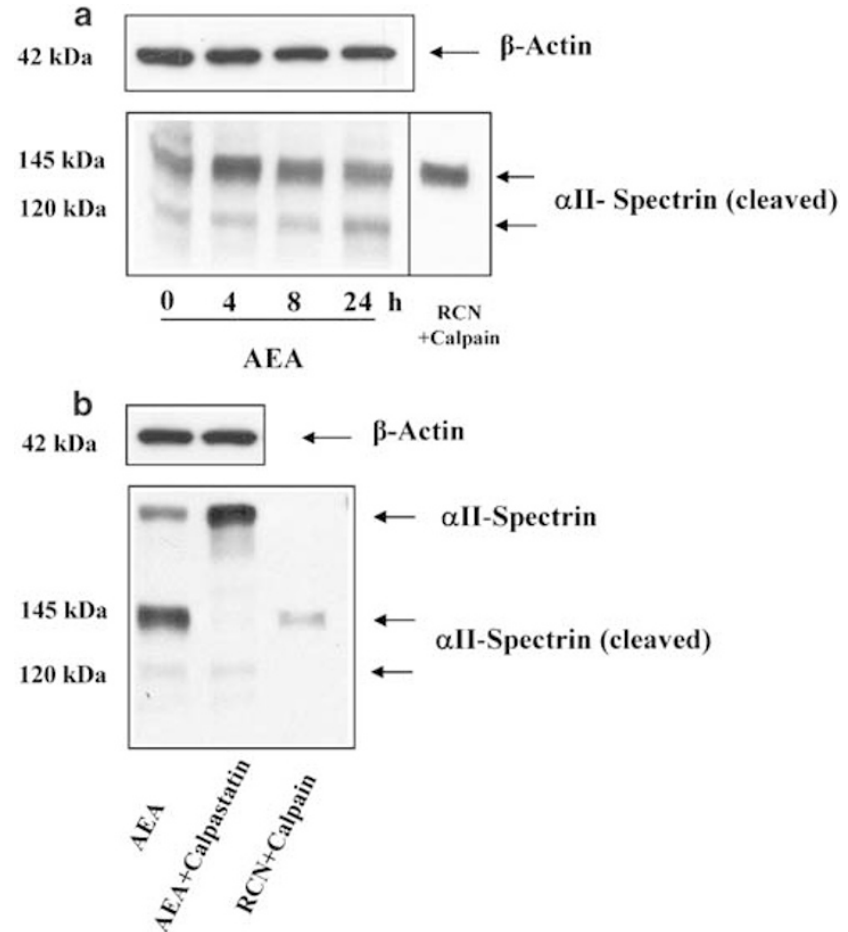

Figure 6 Anandamide induced significant upregulation of cleaved all-spectrin in rat cortical neuronal cultures. Treatment with calpastatin abolishes anandamide-induced $\alpha$ ll-spectrin cleavage. Cultures were treated with $30 \mu \mathrm{M}$ anandamide and after indicated periods of time, harvested, fractionated by $5 \%$ SDS-PAGE and subjected to immunoblot analysis as described in Materials and Methods (a). Cells were pretreated for 30 min with $25 \mu \mathrm{M}$ calpastatin, followed by the addition of $30 \mu \mathrm{M}$ anandamide, and after $4 \mathrm{~h}$ of incubation harvested, fractionated by $5 \%$ SDS-PAGE and subjected to immunoblot analysis (b). To ensure equal protein loading aliquots from the same samples were subjected to $12 \%$ SDS-PAGE following by immunoblot analysis using $\beta$-actin antibody. A measure of $25 \mu \mathrm{g}$ of protein from rat cortical neuronal cell lysates incubated with m-calpain, as described in Materials and Methods, were used as a positive control for cleaved $\alpha$ ll-spectrin (RCN + calpain)

a known action of anandamide, ${ }^{15,44,45}$ we examined effects of anandamide on $\mathrm{Ca}^{2+}$ levels in cortical neuronal cells. We employed imaging analysis using the fluorescent indicator Fluo-3 for assessment of intracellular free calcium ion concentration. As shown in Figure $8, \mathrm{Ca}^{2+}$ levels were significantly increased in cortical neurons treated with anandamide in the presence of $1 \mathrm{mM}$ extracellular $\mathrm{Ca}^{2+}$, whereas in cells incubated in $\mathrm{Ca}^{2+}$-free solution anandamide 

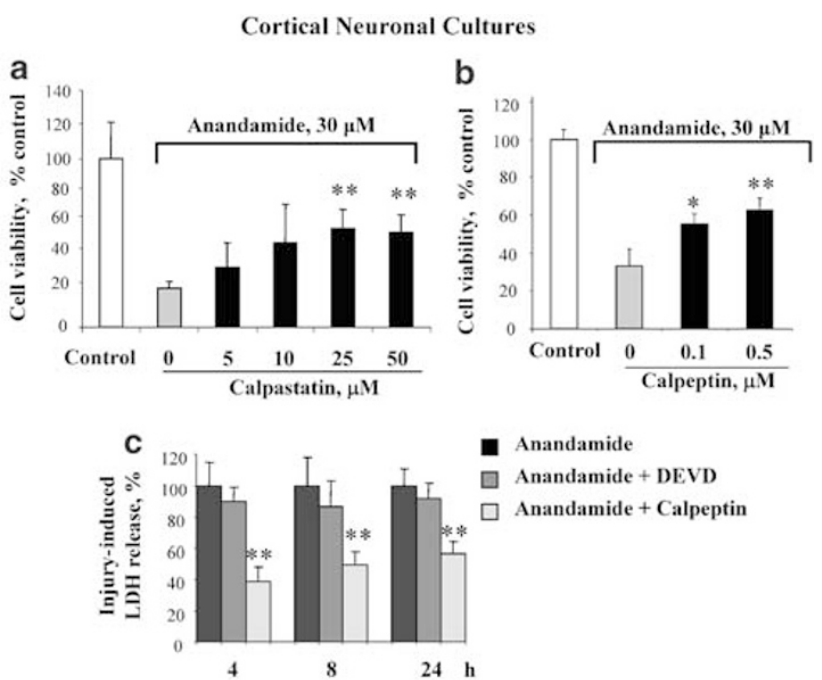

Anandamide + DEVD $\square$ Anandamide + Calpeptin
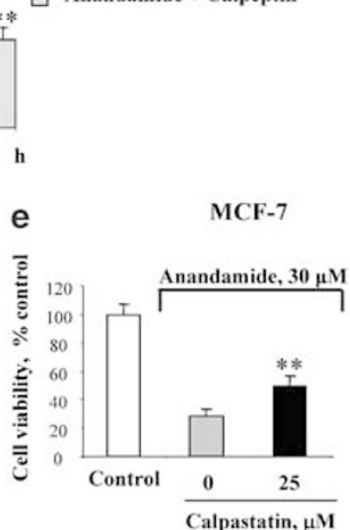

Figure 7 Pretreatment with the calpain inhibitors reduced anandamideinduced cell death in rat cortical neuronal cultures, SH-SY5Y, and MCF-7 cells. Cell viability was measured by calcein AM assay $24 \mathrm{~h}$ after incubation with $30 \mu \mathrm{M}$ anandamide with or without 45 min pretreatment with indicated concentrations of calpain inhibitor calpastatin $(\mathbf{a}, \mathbf{d}, \mathbf{e})$ or calpeptin $(\mathbf{b})$. LDH release was measured after indicated periods of time following incubation with $30 \mu \mathrm{M}$ anandamide with or without 45 min pretreatment using $150 \mu \mathrm{M}$ z-DEVD-fmk or $0.1 \mu \mathrm{M}$ calpastatin (c). The data are representative of 3-5 separate experiments. Histograms indicate cell viability (calcein AM fluorescence) as percentage of controls or LDH levels as a percentage of anandamide-induced release + S.D.; $n=8$ cultures per condition; ${ }^{*} P<0.05$ and ${ }^{*} P<0.01$ versus cells treated with anandamide alone compared by ANOVA, followed by the Dunnett's test

did not alter intracellular $\mathrm{Ca}^{2+}$ concentration. Although baseline measurements appear to have slight fluctuations at approximately $10 \mathrm{~s}$ prior to perfusion of anandamide, recorded values were not significantly different from baseline values. Such fluctuation was periodically caused by the proximity of the $\mathrm{Y}$-tubing perfusion system to the region of interest.

\section{Anandamide reduces mitochondrial membrane potential and causes cytochrome $c$ translocation, which can be attenuated by calpain inhibition}

We also have investigated whether anandamide-induced cell death in cortical neuronal cultures is associated with changes in mitochondrial membrane potential and cytochrome $c$ release. Evaluation of changes in mitochondrial membrane potential by assessments of the emission shifts in JC-1 fluorescence revealed significant decrease of mitochondrial membrane potential in anandamide-treated cells (Figure 9). Immunoblot analysis of protein extracts from the cells

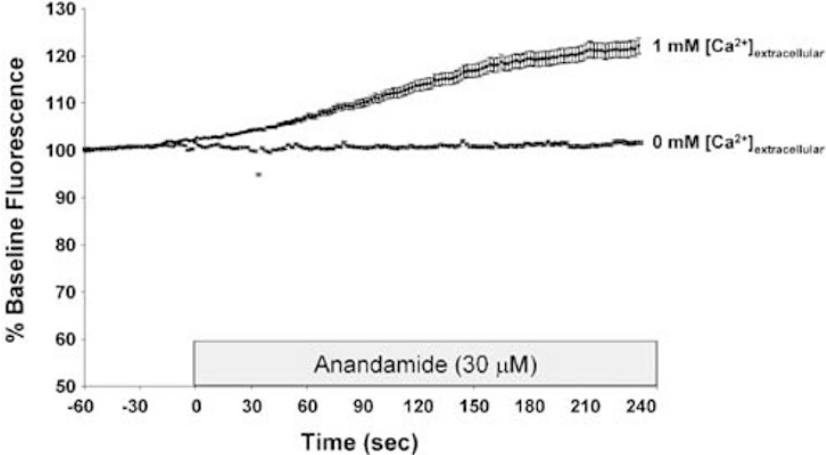

Figure 8 Anandamide increased intracellular $\mathrm{Ca}^{2+}$ levels in rat cortical neuronal cells. Cortical neuronal cells cultured on glass coverslips were loaded with $2 \mu \mathrm{M}$ Fluo-3, and then treated with $30 \mu \mathrm{M}$ anandamide in the presence or absence of $1 \mathrm{mM} \mathrm{CaCl}$; after indicated time periods, Fluo-3 fluorescence was measured using a Sensicam digital fluorescence imaging system as described in Materials and Methods. Anandamide significantly increased intracellular calcium from baseline levels in the presence, but not absence, of $1 \mathrm{mM}$ extracellular $\mathrm{Ca}^{2+}, 30 \mathrm{~s}$ after initial perfusion; $\mathrm{Ca}^{2+}$ levels remained increased throughout the remainder of the experiment $(n=126, P<0.05$ compared by ANOVA followed by the Bonferroni/Dunn test). Data are expressed as a percentage of mean baseline control \pm S.E.

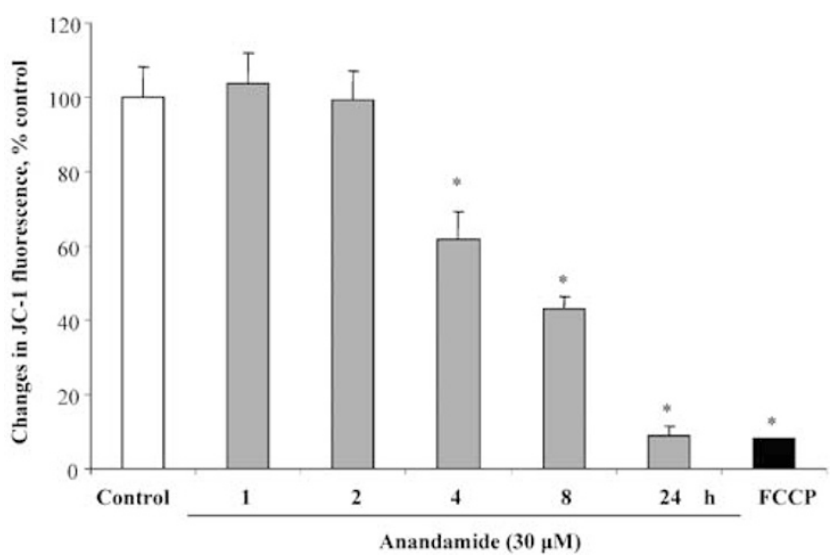

Figure 9 Anandamide induced changes in mitochondrial membrane potential. Cortical neurons cultured in 24-well plates were incubated for 30 min with JC-1 followed by the addition of $30 \mu \mathrm{M}$ anandamide. After indicated periods of time, changes in mitochondrial membrane potential $\left(\Delta \psi_{\mathrm{m}}\right)$ associated with alterations in the red/green fluorescence intensity ratio of $\mathrm{JC}-1$ were measured as described in Materials and Methods. Cells treated for $2 \mathrm{~h}$ with $10 \mu \mathrm{M}$ carbonyl cyanide-4trifluoromethoxyphenylhyrazone (FCCP) were used as a positive control for $\left(\Delta \psi_{\mathrm{m}}\right)$ decrease. The data are representative of three separate experiments. Each individual treatment/time point reflects four replicates. ${ }^{*} P<0.01$ versus untreated controls compared by ANOVA, followed by the Dunnett's test

incubated with anandamide showed marked upregulation in cytochrome $c$ protein levels in the cytosol (Figure 10a). Application of caspase-3 inhibitor z-DEVD-fmk did not alter anandamide-stimulated cytochrome $c$ translocation, whereas incubation with calpastatin significantly attenuated upregulation of cytochrome $c$ levels in cytosolic extracts from anandamide-treated cortical neurons (Figure 10b). Moreover, administration of calpastatin markedly decreased anandamide-induced elevation of active caspase-3 levels, as revealed by immunoblot assay (Figure 10c). 


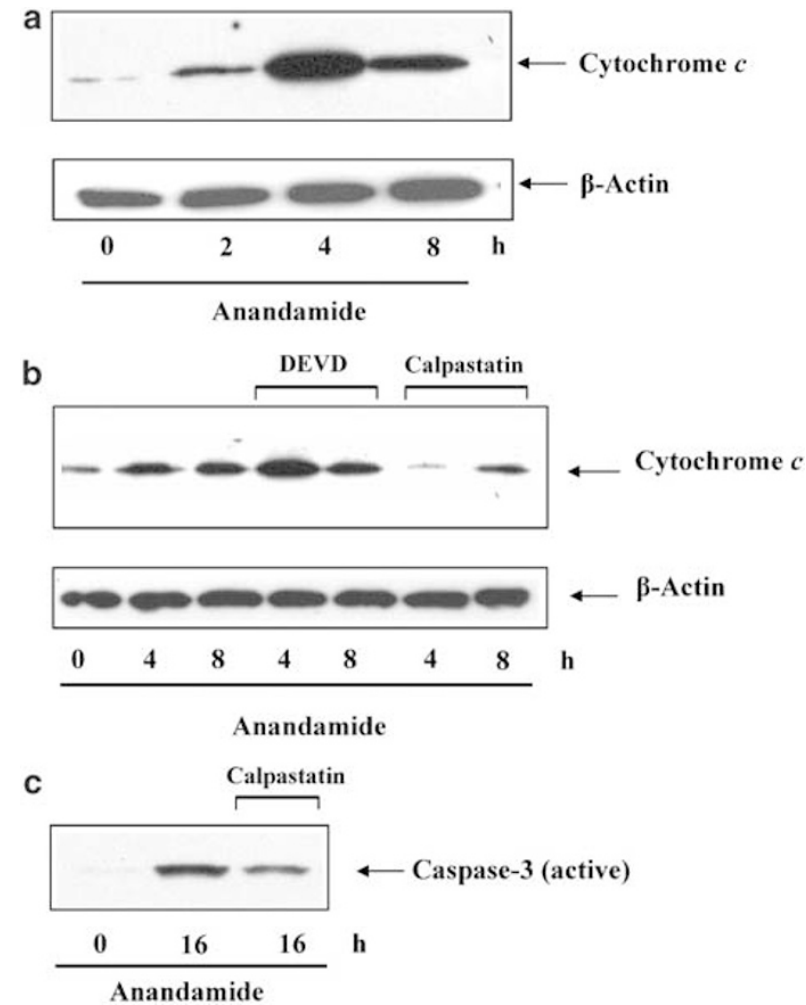

Figure 10 Immunoblot analysis of anandamide-treated rat cortical neuronal cultures revealed significant upregulation of cytochrome $c$ protein levels in the cytosol (a). Treatment with calpastatin-attenuated anandamide-induced cytochrome $c$ release (b). Administration of calpastatin reduced levels of active caspase-3 in anandamide-treated cultures (c). Cultures were treated with $30 \mu \mathrm{M}$ anandamide with or without 45 min pretreatment with $150 \mu \mathrm{M}$ z-DEVD-fmk or $25 \mu \mathrm{M}$ calpastatin and after indicated time periods harvested and subjected to immunoblot analysis as described in Materials and Methods. $\beta$-Actin was used as an internal control

\section{Discussion}

Endocannabinoids have generally been considered to provide neuroprotection, through actions at $\mathrm{CB}$ receptors. For example, 2-AG has been shown to reduce edema formation and enhance functional recovery after brain injury in mice. ${ }^{46}$ Similarly, neuroprotective effects for anandamide have been reported in a rat model of ouabaininduced acute brain injury, ${ }^{21}$ as well as in neuronal cell cultures, where low doses of anandamide $(0.1-0.3 \mu \mathrm{M})$ protected cells exposed to hypoxia and glucose deprivation. ${ }^{47}$ In contrast, we have recently found that anandamide induces neuronal cell loss after intracerebroventricular (icv) injections in rat brain (I Cernak et al., unpublished observation). Anandamide has also been reported to induce apoptosis in human neuroblastoma cell line, ${ }^{17}$ and suppress glial cell proliferation. ${ }^{16}$

In the present study, we found that the administration of anandamide, in a dose-dependent manner, caused cell death in cultured rat cortical neurons and cerebellar granule cells. These results are supported by our parallel work showing that significantly low doses of anandamide $(0.1-1 \mu \mathrm{M})$ exacerbate injury-induced cell death of CGC subjected to trophic support/ potassium withdrawal; in addition, anandamide increased neuronal cell death caused by stretch injury in vitro (I Cernak et al., unpublished observation). Doses of anandamide, which were effective in our noninjured cell culture systems, are higher that those required for receptor activation. ${ }^{24,48}$ However, since it has been shown that brain injury in rats is associated with significant (up to 14-fold) upregulation of AEA levels in the ipsilateral cortex, ${ }^{18}$ our in vitro models of anandamide-induced cell death may represent pathophysiological events acquired following neuronal injury.

We also observed cell death following administration of nondegradable anandamide analog meth-anadamide or after blockade of anandamide breakdown by FAAH inhibition using PMSF; together, these observations suggest that anandamide by itself, rather than products of its degradation, may be responsible for the observed neurotoxic effects. Moreover, exacerbation of anandamide-induced cell death by PMSF may reflect additional neurotoxic effects of endogenous AEA upregulated by the suppression of FAAH activity.

Inhibition of cannabinoid receptors (both CB1 and CB2), vanilloid receptors (VR1), or NMDA receptors did not reduce anandamide-induced neuronal loss in $\mathrm{RCN}$, indicating that these receptors do not mediate the toxic effects of anandamide in this primary neuronal culture. These findings are consistent with the recent work of Sarker and Maruyama, ${ }^{49}$ showing lack of effects of CB1, CB2 and VR1 antagonists on anandamide-induced death in cell lines. Anandamide-induced cell death in cortical neuronal cultures was associated with increased numbers of cells showing apoptotic morphology, reduction of the mitochondrial membrane potential, translocation of cytochrome $c$, upregulation of active caspase-3 protein levels, and enhanced caspase-3-like enzymatic activity. Changes in the mitochondrial membrane potential and translocation of cytochrome $c$ have been implicated in the formation of the apoptosome and activation of caspase- 9 , leading to activation of caspase- 3 and associated apoptosis. ${ }^{50}$ Although we indeed measured changes in caspase-3 activity following anandamide administration, treatment with caspase inhibitors at concentrations previously shown to be able to attenuate classical caspase-3-mediated apoptosis in neuronal cell cultures ${ }^{30,31}$ did not modify anandamideinduced cell death. Thus, coadministration of selective caspase-3 inhibitor z-DEVD-fmk failed to provide neuroprotection against anandamide-induced cell death. Moreover, no protection was observed by suppression of caspase-8 or -9 , the upstream regulatory caspases, which control caspase-3 activity and modulate the extrinsic or intrinsic pathways of neuronal apoptosis, respectively. ${ }^{51-54}$ In addition, anandamide-induced cytotoxicity appeared prior to changes in caspase activity. These findings were further confirmed using neuroblastoma cell lines that expressed either caspase- 9 or -8 dominant-negative mutants; again, anandamide-induced cell death was not modified in cells transfected with the dominantnegative constructs versus the empty vector. Moreover, anandamide caused cell death in caspase-3-deficient MCF7 cells. Collectively, these results suggest that caspasedriven apoptosis, which can be detected by caspase activation and morphological changes in cultures exposed to anandamide, is not a major contributor to anandamidegenerated neuronal cell death. 
It has been suggested that de novo protein synthesis may be essential for activation of caspase-regulated apoptosis. ${ }^{32,55,56}$ Consistent with the studies using caspase inhibitors, inhibition of protein synthesis did not protect cortical neurons from the neurotoxic effects of anandamide. In contrast, parallel studies using treatment with etoposide, a classical method of inducing caspase-3-mediated neuronal apoptosis, showed cycloheximide blockade of apoptosis. Together, these findings indicate that protein synthesisindependent pathways are involved in anandamide-induced neuronal cell loss.

The present findings suggest an important role for calpain in cell death induced by anandamide. The calpain inhibitors calpastatin and calpeptin showed significant protective effects on anandamide-induced cell death in cortical neuronal cultures. Although, these calpain inhibitors demonstrated considerable neuroprotective activity in this model, they did not block cell death completely. This may reflect, in part, the limited cell permeability of these compounds. Alternatively, there may be additive (multiple) mechanisms of cell death, which can be triggered at different time periods after injury, as suggested previously by our work on caspase inhibitormediated neuroprotection. ${ }^{31}$ In addition, anandamide stimulated calpain activity (i.e. $\alpha$ ll-spectrin cleavage) in cortical neurons; this effect was abolished by treatment with a calpain inhibitor. Calpain activation has previously been reported in anandamide-induced inhibition of C6 glioma cell proliferation. ${ }^{16} \mathrm{~A}$ role for calpain-related pathways in neuronal cell death has also been well demonstrated previously in various in vitro and in vivo models of neuronal injury. ${ }^{36,41,42}$ Moreover, we have also recently found that icv administration of anandamide in rats causes cerebral edema and neuronal cell loss which are attenuated by calpain inhibitors (I Cernak et al., unpublished observation).

Treatment with anandamide caused significant upregulation of intracellular $\mathrm{Ca}^{2+}$ levels, which can serve as a trigger for calpain activation. The observed increase of $\mathrm{Ca}^{2+}$ concentration appeared to reflect influx from the extracellular environment, but not the release of $\mathrm{Ca}^{2+}$ from intracellular compartments, as $\mathrm{Ca}^{2+}$ upregulation was not detected when cortical neurons were incubated with anandamide in a $\mathrm{Ca}^{2+}$-free medium. This conclusion is supported by pilot studies indicating that calcium channel blockers, such as $\omega$-agatoxin TK or calcicludine reduce anandamide toxicity (data not shown).

Anandamide-induced calpain activation in cortical neuronal cells also caused cytochrome $c$ release from mitochondria, which was blocked by treatment with a calpain inhibitor. It is known that m-calpain activation may cause subsequent increases in caspase activity through direct cleavage/activation of caspase- $3 ;^{37}$ it may also cause truncation of $\mathrm{Bcl}-2$ or Bid, which induces cytochrome $c$ release from mitochondria, followed by initiation of the intrinsic apoptotic pathway. ${ }^{57}$ That anandamide-induced calpain activation may contribute to caspase activation, which appeared at later time points in our model, is supported by our finding showing that levels of active caspase-3 can be significantly reduced by calpain inhibition in anandamide-treated cortical neurons. This also suggests that anandamide-mediated calpain activation in cortical cultures is upstream of caspase stimulation. Together, these observa- tions indicate that anandamide causes neuronal cell death through mechanisms that do not appear to involve known cannabinoid or vanilloid receptors, but rather reflect activation of calpain-related pathways.

\section{Materials and Methods}

\section{Cell cultures}

\section{Rat cortical neuronal cultures}

Cortical neuronal cultures were derived from rat embryonic cortices (Taconic, Germantown, NY, USA) as previously described. ${ }^{58}$ Briefly, cortices from 17 to 18-day-old Sprague-Dawley rat embryos were cleaned from meninges and blood vessels in Krebs-Ringers bicarbonate buffer containing $0.3 \%$ bovine serum albumin (BSA), (Gibco, Gaithersburg, MD, USA). Cortices were minced and dissociated in the same buffer with $1800 \mathrm{U} / \mathrm{ml}$ trypsin (Sigma, St. Louis, MO, USA) at $37^{\circ} \mathrm{C}$ for $20 \mathrm{~min}$. Following the addition of $200 \mathrm{U} / \mathrm{ml}$ DNase I (Sigma) and $3600 \mathrm{U} / \mathrm{ml}$ soybean trypsin inhibitor (Sigma) to the suspension, cells were triturated through a $5 \mathrm{ml}$ pipet. After the tissue was allowed to settle for 5-10 $\mathrm{min}$, the supernatant was collected, and the remaining tissue pellet was retriturated. The combined supernatants were centrifuged through a $4 \%$ BSA layer and the cell pellet was resuspended in neuronal seeding medium (NSM), which consisted of Neurobasal Medium (Gibco) supplemented with $1.1 \% 100 \times$ antibiotic-antimycotic solution (Biofluids), $25 \mu \mathrm{M}$ Na-glutamate, $0.5 \mathrm{mM}$ L-glutamine, and 2\% B27 Supplement (Gibco). Cells were seeded at a density of $5 \times 10^{5}$ cells $/ \mathrm{ml}$ onto 96-well tissue culture plates (Corning, Corning, NY, USA) precoated with poly-Dlysine (70-150 kDa, Sigma), or on $100 \mathrm{~mm}$ Petri dishes (Corning) precoated with poly-D-lysine. On day 4 in vitro (DIV), feeding media (NSM without Na-glutamate and B27 supplement) in $1: 2$ proportion was added to cultures. All experiments were performed on cultures at 7-9 DIV.

\section{Cerebellar granule cells (CGC)}

CGC cultures were prepared as previously described. ${ }^{59}$ Briefly, the meninges and blood vessels were removed from cerebella of 7-day-old Sprague-Dawley rat pups (Taconic) while in Krebs-Ringer's bicarbonate buffer containing $0.3 \%$ bovine serum albumin (BSA, Gibco, Gaithersburg, MD, USA). The cerebella were dissociated at $37^{\circ} \mathrm{C}$ for $20 \mathrm{~min}$. in the same buffer with the addition of $1800 \mathrm{U} / \mathrm{ml}$ trypsin (Sigma, St. Louis, MO, USA). The dissociated cells were triturated through a $5 \mathrm{ml}$ pipette following the addition of $200 \mathrm{U} / \mathrm{ml}$ DNase I (Sigma) and $3600 \mathrm{U} / \mathrm{ml}$ soybean trypsin inhibitor (Sigma). The supernatant was collected after the tissue settled for 5-10 min; the pellet was retriturated as noted above. The supernatants were combined and centrifuged through a $4 \%$ BSA solution. The pellet was resuspended in seeding medium containing Neurobasal Medium (Gibco), $25 \mathrm{mM} \mathrm{KCl}, 0.5 \mathrm{mM}$ L-glutamine, $50 \mu \mathrm{g} / \mathrm{ml}$ gentamicin, and $2 \%$ B27 supplement (Gibco). Cells were seeded at $5 \times 10^{5}$ cells $/ \mathrm{ml}$ onto 96 well tissue culture plates (Corning, Corning, NY, USA) precoated with poly-D-lysine (70-150 kDa, Sigma). All experiments were performed at day 7 in vitro (DIV).

\section{SH-SY5Y and MCF-7 cell lines}

SH-SY5Y human neuroblastoma and breast cancer MCF-7 cells were routinely cultured in DMEM (Gibco) supplemented with 10\% FBS (Hyclone Laboratories, Inc., Logan, UT, USA), $50 \mathrm{U} / \mathrm{ml}$ penicillin/streptomycin, and $5 \mu \mathrm{g} / \mathrm{ml}$ fungizone (Biofluids) in $250 \mathrm{ml}$ flasks (Corning). For experiments, cells were detached from the surface by trypsin-EDTA solution (Gibco), resuspended in fresh media and seeded at $2 \times 10^{5}$ cells/ml onto 96-well 
tissue culture plates (Corning, Corning, NY, USA) precoated with poly-Dlysine $(70-150 \mathrm{kDa}$, Sigma).

\section{Development of stable SH-SY5Y lines expressing dominant-negative caspase forms}

SH-SY5Y neuroblastoma cells were stable transfected with pcDNA3 vector expressing dominant-negative forms of human caspases- 8 or -9 as previously described. ${ }^{30}$ Briefly, transfections were performed using lipofectamine reagent (Gibco) and stable transfectants were pooled after selection for 2 weeks in the presence of $\mathrm{G} 418(1 \mathrm{mg} / \mathrm{ml})$. Constructs expressing dominant-negative forms of human caspases-8 and -9 were kindly provided by Dr. Vishva M Dixit. In the inactive mutant form of caspase-8, cysteine residue at its active site QACQG was changed to serine. In the dominant-negative form of caspase-9, cysteine residue at its active site QACGG was changed to alanine. In addition, both mutants were fused with a FLAG epitope at their C-termini. Previous studies by $\mathrm{Dr}$ Dixit's group have demonstrated that expression of these mutants in mammalian cells potently and specifically inhibits activation of caspases-8 and $-9 .{ }^{60}$ Expression of the recombinant mutant caspases was confirmed by immunoblotting using the anti-FLAG (Santa Cruz, Santa Cruz, CA, USA), anticaspase-8 (Apotech, Epalinges, Switzerland) and anticaspase9 (MBL, Naka-ku Nagoya, Japan) antibodies (data not shown). Stable cell clones transfected with the empty pcDNA3 vector served as a negative control.

\section{Induction of cell death in neuronal cultures}

Stock solutions of anandamide (pure oil) or meth-anandamide (both from Tocris) dissolved in ethanol were then diluted in culture medium and added to rat primary neuronal cultures (CGC; RCN) or to cell lines (SHSY5Y; MCF-7) preincubated overnight in B27-free Neurobasal or serumfree DMEM medium, respectively. In experiments using combined treatments, anandamide was administered to cultures after pretreatment with capsazepine, isovelleral, AM251, AM630, MK801 (all from Tocris), ruthenium red, cycloheximide, PMSF (all from Sigma), z-DEVD-fmk, zLEHD-fmk, z-IETD-fmk (all from Enzyme Systems), calpastatin, or calpeptin (both from Calbiochem). Control cultures received vehicle alone. It should be noted that anandamide (pure oil) (Tocris,\#1339) was chosen for this study because our pilot experiments showed substantial cytotoxic effect of soya oil/water emulsion used by the manufacturer as a vehicle for the anandamide in water-soluble emulsion (Tocris, \#1017). This vehicle caused cell death starting at dilutions equal to $1 \mu \mathrm{M}$ of the drug (data not shown).

\section{Cell viability assays}

Cell viability was measured by LDH release assay ${ }^{61}$ or retention and deesterification of calcein acetoxymethyl (AM) as described previously. ${ }^{31}$ $\mathrm{LDH}$ release was measured using CytoTox 96 nonradioactive cytotoxicity assay kit (Promega) according to the manufacturer's protocol. Relative absorbance was measured at $490 \mathrm{~nm}$ using a Multiscan Ascent microplate reader (Labsystems Inc., Helsinki, Finland). Background LDH release determined in intact control cultures was subtracted from all experimental values. For calcein AM assay, culture medium in 96-well plates was replaced with $5 \mu \mathrm{M}$ calcein AM (Molecular Probes, Eugene, OR, USA) in Locke's buffer containing $154 \mathrm{mM} \mathrm{NaCl}, 5.6 \mathrm{mM} \mathrm{KCl}, 3.6 \mathrm{mM} \mathrm{NaHCO}_{3}$, $2.3 \mathrm{mM} \mathrm{CaCl}_{2}, 1.2 \mathrm{mM} \mathrm{MgCl}_{2}, 5.6 \mathrm{mM}$ glucose, and $5 \mathrm{mM} \mathrm{HEPES}$, pH 7.4 After incubation at $37^{\circ} \mathrm{C}$ for $30 \mathrm{~min}$, fluorescence was measured using a
CytoFluor II fluorometer (PerSeptive Biosystems, Framingham, MA, USA) at $485 \mathrm{~nm}$ excitation and $560 \mathrm{~nm}$ emission wavelengths.

\section{Hoechst staining}

Cells were washed in PBS and stained for $10 \mathrm{~min}$ at room temperature in PBS containing $4 \%$ paraformaldehyde and $10 \mu \mathrm{g} / \mathrm{ml}$ Hoechst 33258 (Sigma). Morphological evaluation of nuclear condensation and fragmentation was performed immediately after staining using a Nikon TE300 fluorescent microscope. The number of cells with apoptotic morphology was assessed in five randomly chosen fields; $300-400$ cells per condition were counted.

\section{Assay for caspase activity}

Cells cultured in 96-well plates were lysed for $20 \mathrm{~min}$ at $4^{\circ} \mathrm{C}$ in $100 \mu \mathrm{l} /$ well of caspase-3 assay buffer consisting of $50 \mathrm{mM}$ HEPES, pH 7.4, $100 \mathrm{mM}$ $\mathrm{NaCl}, 0.1 \%$ CHAPS, $10 \mathrm{mM}$ DTT, $1 \mathrm{mM}$ EDTA, and $10 \%$ glycerol, then $40 \mu \mathrm{M}$ of fluorescent tetrapeptide substrate (Ac-DEVD-AMC, Bachem) was added. Free aminomethylcoumarin (AMC) accumulation, which resulted from cleavage of the aspartate-AMC bond, was monitored continuously in each sample over $30 \mathrm{~min}$ in the same 96-well microtiter plates using a CytoFluor 4000 fluorometer (PerSeptive Biosystems) at $360 \mathrm{~nm}$ excitation and $460 \mathrm{~nm}$ emission wavelengths. The emission from each well was plotted against time. Linear regression analysis of the initial velocity (slope) of each curve yielded an activity for each sample. Results were normalized to protein level in each well measured at $620 \mathrm{~nm}$ using a Multiscan Ascent microplate reader (Labsystems Inc., Helsinki, Finland) after staining with Protein Assay Reagent (Bio-Rad Laboratories, Inc., Hercules, CA, USA).

\section{Measurement of mitochondrial membrane potential $\left(\Delta \psi_{\mathrm{m}}\right)$}

Rat primary cortical neurons were cultured in 24-well plates. After various treatments $5,5^{\prime}, 6,6^{\prime}$-tetrachloro-1, 1'3, 3'-tetraethyl-benzimidazolylcarbocyanine iodide (JC-1) was added to each well at a final concentration of $2.5 \mu \mathrm{M}$. The plates were kept in the incubator for an additional $30 \mathrm{~min}$, and the tissue culture supernatant was removed and replaced with $1 \mathrm{ml}$ of HBSS. The JC- 1 fluorescence was sequentially measured at emission 530 and $590 \mathrm{~nm}$ with excitation at $480 \mathrm{~nm}$ in a CytoFluor 4000 fluorometer (PerSeptive Biosystems). JC-1 has a potential-dependent accumulation in the mitochondria demonstrated by a fluorescence emission shift from green $(530 \mathrm{~nm})$ to red $(590 \mathrm{~nm})$. A decrease in mitochondrial membrane potential $\left(\Delta \psi_{\mathrm{m}}\right)$ is associated with a decrease in the red/green fluorescence intensity ratio. We calculated the ratio between fluorescence intensity at 590 and $530 \mathrm{~nm}$ for each well and expressed the ratio in treated samples as a percentage control, as previously described. ${ }^{62}$ Each individual treatment/time point reflects four replicates.

\section{Immunoblot analysis}

Cells were harvested, washed once with ice-cold phosphate-buffered saline, and lysed on ice in a solution containing $50 \mathrm{mM}$ Tris- $\mathrm{HCl}(\mathrm{pH} 7.5)$, $150 \mathrm{mM} \mathrm{NaCl}, 1 \mathrm{mM}$ EGTA, $1 \mathrm{mM}$ PMSF, 1\% NP-40, 0.5\% sodium deoxycholate, $0.1 \%$ SDS, leupeptin $(5 \mathrm{mg} / \mathrm{ml})$, and aprotinin $(5 \mathrm{mg} / \mathrm{ml})$. After removal of cell debris by centrifugation, the protein concentration of the cell lysate was determined with the BioRad protein assay reagent. A portion of the lysate (50 $\mu \mathrm{g}$ of protein) was then fractionated by 
SDS-polyacrylamide gel electrophoresis (PAGE); 5 or $12 \%$ gels (Bio-Rad) were used for immunoblot analysis of $\alpha$ ll-spectrin or caspase-3/cytochrome $c$, respectively. After separation by PAGE proteins were transferred to a nitrocellulose membrane (Bio-Rad). The membrane was stained with Ponceau S (Sigma) to confirm equal loading and transfer of samples, and was then probed with specific antibodies. Immune complexes were detected with appropriate secondary antibodies and chemiluminescence reagents (Pierce). A polyclonal rabbit antibody to active caspase-3 was obtained from Cell Signaling Technology (New England Biolabs), a monoclonal mouse antibody to cytochrome $c$ from BD Bioscience (Palo Alto, CA, USA), a monoclonal mouse antibody to $\alpha$ ll-spectrin - from Affiniti Research Products (Mamhead, UK), and a monoclonal mouse antibody to $\beta$-actin - from Sigma. A measure of $300 \mu \mathrm{g}$ of protein from cell lysates of intact rat cortical neuronal cultures were incubated $45 \mathrm{~min}$ at $37^{\circ} \mathrm{C}$ with $5 \mathrm{U}$ of recombinant m-calpain (Calbiochem, San Diego, CA, USA) in buffer containing $5 \mathrm{mM} \mathrm{CaCl}_{2}, 50 \mathrm{mM}$ HEPES, (pH 7.4), $100 \mathrm{mM} \mathrm{NaCl}, 1 \mathrm{mM}$ EDTA, $10 \mathrm{mM}$ DTT, $0.1 \%$ CHAPS, $10 \%$ glycerol. A measure of $25 \mu \mathrm{g}$ of protein from $\mathrm{m}$-calpain-treated lysates were utilized in immunoblot assays as a positive control for $\alpha$ ll-spectrin cleavage.

\section{Assay of cytochrome c release}

Cytochrome $c$ release in the cytosol was assessed after subcellular fractionation as described, ${ }^{63}$ with some modifications. The culture media from $10 \mathrm{~cm}$ dishes containing rat cortical neurons was aspirated and $5 \mathrm{ml}$ of Trypsin-EDTA solution (Invitrogen) was added. The dishes were incubated for $3 \mathrm{~min}$ at $37^{\circ} \mathrm{C}$ and then $4.5 \mathrm{ml}$ of the Trypsin-EDTA solution was aspirated and the dishes were incubated again at $37^{\circ} \mathrm{C}$ for $7 \mathrm{~min}$. The cells were gently detached from the substrate in $10 \mathrm{ml}$ of Neurobasal Medium and the cell suspension was centrifuged at $500 \times g$ for $15 \mathrm{~min}$ at $4{ }^{\circ} \mathrm{C}$. The supernatant was aspirated and the cell pellet was resuspended in $100 \mu \mathrm{l}$ of lysis buffer containing $\mathrm{KH}_{2} \mathrm{PO}_{4} 1.06 \mathrm{mM}, \mathrm{NaCl} 155.17 \mathrm{mM}$, $\mathrm{Na}_{2} \mathrm{HPO}$ - $7 \mathrm{H}_{2} \mathrm{O} 2.96 \mathrm{mM}, \mathrm{KCl} 80 \mathrm{mM}$, sucrose $250 \mathrm{mM}$, AEBSF $1 \mathrm{mM}$, aprotinin $10 \mu \mathrm{g} / \mathrm{ml}$, pepstatin $1 \mu \mathrm{M}$, digitonin $0.1 \mathrm{mg} / \mathrm{ml}(\mathrm{pH} \mathrm{7.4)}$ and incubated at $4^{\circ} \mathrm{C}$ for $5 \mathrm{~min}$. The lysate was centrifuged at $15000 \times \mathrm{g}$ for $15 \mathrm{~min}$ at $4^{\circ} \mathrm{C}$. The supernatant was transferred to a new tube, centrifuged again at $15000 \times g$ for $15 \mathrm{~min}$ at $4^{\circ} \mathrm{C}$ and the resulting supernatant, representing the cytosolic fraction, was recovered. A measure of $25 \mu \mathrm{g}$ of protein from the cytosolic fraction were analyzed by immunoblotting using an anti-cytochrome $c$ monoclonal antibody, clone $7 \mathrm{H} 8.2 \mathrm{C} 12$ (BD Biosciences, Palo Alto, CA, USA).

\section{Calcium imaging}

Cells were loaded with fluo-3 by incubation with $2 \mu \mathrm{M}$ fluo-3 acetoxymethyl (AM) ester (Molecular Probes Inc.; Eugene, OR, USA) in Neurobasal Medium without phenol red (Gibco) for $30 \mathrm{~min}$, followed by a 30-min deesterification period. ${ }^{64}$ All incubations and experiments were carried out at room temperature $\left(23.5^{\circ} \mathrm{C}\right)$. Imaging was performed by transferring a single glass coverslip into a perfusion chamber mounted on a Zeiss 135 inverted microscope equipped with a $100 \mathrm{~W}$ mercury arc lamp (RatioArc; Atto Instruments). Cells were perfused continuously with extracellular perfusion media: $145 \mathrm{mM} \mathrm{NaCl}, 5 \mathrm{mM} \mathrm{KCl}, 1 \mathrm{mM} \mathrm{CaCl}, 1 \mathrm{mM} \mathrm{MgCl}$, $5 \mathrm{mM}$ HEPES, $5 \mathrm{mM}$ glucose, and $20 \mu \mathrm{M}$ glycine. Osmolarity was adjusted to 325 mosm with sucrose, and $\mathrm{pH}$ adjusted to 7.4 with $\mathrm{NaOH}$. Drugs were diluted to final concentration in extracellular perfusion media. Application of drugs to the cells was via $Y$ tubing controlled by a BPS-4 valve control system (Scientific Instruments, New York). Fluo-3 fluorescence was measured using a Sensicam digital fluorescence imaging system (Cooke Corp., Auburn Hills, MI, USA) controlled by IPLab imaging software
(Scanalytics Inc., Fairfax, VA, USA). The mercury lamp was used at full power for all of the experiments with a neutral density filter in place. Excitation light for fluo-3 was filtered through a 460-500 nm excitation filter and reflected by a $505 \mathrm{~nm}$ dichroic mirror before being focused through a x10 objective lens (Zeiss Fluar x10) onto the cells in the perfusion chamber. The emitted light was transmitted by the dichroic mirror before being filtered by a $510-560 \mathrm{~nm}$ filter. Image capture and analysis was performed using the IPLab imaging software. Calcium imaging fluorescence measurements were normalized to percentages of the mean baseline value. Only cells exhibiting a steady baseline (1 min before drug application) were considered for further analysis.

\section{Data analysis}

Changes in cell viability and mitochondrial membrane potential were analyzed by ANOVA, followed by the Dunnett's test. Statistical analysis of anandamide-induced increase in fluo-3 intensity was carried out using an ANOVA, followed by the Bonferroni/Dunn test. Comparisons of alterations in caspase-like enzymatic activity between treated and control cultures were analyzed using two-tailed $t$-tests. A $P$-value less than 0.05 was considered statistically significant.

\section{Acknowledgements}

This study was supported by grants from the National Institutes of Health (NS 36537-03) and the Department of Defense (DAMD 17-2-9007). We are grateful to $\mathrm{Dr}$. Vishva M Dixit for kindly providing constructs expressing dominant-negative forms of caspase-8 and caspase-9. We also thank Ms. Elvira A Dabaghyan and Ms. Lioudmila Zoubak for excellent technical assistance in cell viability assays, measurements of caspase activity, and immunoblot analysis, and Ms. Jennifer Fennell for help in the preparation of the manuscript.

\section{References}

1. Fride $E$ (2002) Endocannabinoids in the central nervous system-an overview. Prostaglandins Leukot. Essent. Fatty Acids 66: 221-233

2. van der Stelt M, Veldhuis WB, Maccarrone M, Bar PR, Nicolay K, Veldink GA, Di Marzo V and Vliegenthart JF (2002) Acute neuronal injury, excitotoxicity, and the endocannabinoid system. Mol. Neurobiol. 26: 317-346

3. Di Marzo V, Fontana A, Cadas H, Schinelli S, Cimino G, Schwartz JC and Piomelli $D$ (1994) Formation and inactivation of endogenous cannabinoid anandamide in central neurons. Nature 372: 686-691

4. Hansen HS, Moesgaard B, Hansen HH, Schousboe A and Petersen G (1999) Formation of $\mathrm{N}$-acyl-phosphatidylethanolamine and $\mathrm{N}$-acylethanolamine (including anandamide) during glutamate-induced neurotoxicity. Lipids 34 : S327-S330

5. Maccarrone M and Finazzi-Agro A (2002) Endocannabinoids and their actions. Vitam. Horm. 65: 225-255

6. Thomas EA, Cravatt BF, Danielson PE, Gilula NB and Sutcliffe JG (1997) Fatty acid amide hydrolase, the degradative enzyme for anandamide and oleamide, has selective distribution in neurons within the rat central nervous system. J. Neurosci. Res. 50: 1047-1052

7. Jacobsson SO and Fowler CJ (2001) Characterization of palmitoylethanolamide transport in mouse Neuro-2a neuroblastoma and rat RBL-2H3 basophilic leukaemia cells: comparison with anandamide. Br. J. Pharmacol. 132: $1743-1754$

8. Felder CC, Joyce KE, Briley EM, Mansouri J, Mackie K, Blond O, Lai Y, Ma AL and Mitchell RL (1995) Comparison of the pharmacology and signal transduction of the human cannabinoid $\mathrm{CB} 1$ and $\mathrm{CB} 2$ receptors. Mol. Pharmacol. 48: 443-450 
9. Sugiura T, Kondo S, Kishimoto S, Miyashita T, Nakane S, Kodaka T, Suhara Y, Takayama $\mathrm{H}$ and Waku K (2000) Evidence that 2-arachidonoylglycerol but not $\mathrm{N}$-palmitoylethanolamine or anandamide is the physiological ligand for the cannabinoid CB2 receptor. Comparison of the agonistic activities of various cannabinoid receptor ligands in HL-60 cells. J. Biol. Chem. 275: 605-612

10. Olah Z, Karai $L$ and ladarola MJ (2001) Anandamide activates vanilloid receptor 1 (VR1) at acidic $\mathrm{pH}$ in dorsal root ganglia neurons and cells ectopically expressing VR1. J. Biol. Chem. 276: 31163-31170

11. Smart D, Jonsson KO, Vandevoorde S, Lambert DM and Fowler CJ (2002) 'Entourage' effects of $\mathrm{N}$-acyl ethanolamines at human vanilloid receptors. Comparison of effects upon anandamide-induced vanilloid receptor activation and upon anandamide metabolism. Br. J. Pharmacol. 136: 452-458

12. Smart $D$ and Jerman JC (2000) Anandamide: an endogenous activator of the vanilloid receptor. Trends Pharmacol. Sci. 21: 134

13. Smart D, Gunthorpe MJ, Jerman JC, Nasir S, Gray J, Muir Al, Chambers JK, Randall $A D$ and Davis JB (2000) The endogenous lipid anandamide is a full agonist at the human vanilloid receptor (hVR1). Br. J. Pharmacol. 129: 227-230

14. Hampson AJ, Bornheim LM, Scanziani M, Yost CS, Gray AT, Hansen BM, Leonoudakis DJ and Bickler PE (1998) Dual effects of anandamide on NMDA receptor-mediated responses and neurotransmission. J. Neurochem. 70: 671-676

15. Mombouli JV, Schaeffer G, Holzmann S, Kostner GM and Graier WF (1999) Anandamide-induced mobilization of cytosolic $\mathrm{Ca}^{2+}$ in endothelial cells. Br. J. Pharmacol. 126: 1593-1600

16. Jacobsson SO, Wallin T and Fowler CJ (2001) Inhibition of rat C6 glioma cell proliferation by endogenous and synthetic cannabinoids. Relative involvement of cannabinoid and vanilloid receptors. J. Pharmacol. Exp. Ther. 299: 951-959

17. Maccarrone M, Lorenzon T, Bari M, Melino G and Finazzi-Agro A (2000) Anandamide induces apoptosis in human cells via vanilloid receptors. Evidence for a protective role of cannabinoid receptors. J. Biol. Chem. 275: 31938-31945

18. Hansen HH, Schmid PC, Bittigau P, Lastres-Becker I, Berrendero $F$ Manzanares J, Ikonomidou C, Schmid HH, Fernandez-Ruiz JJ and Hansen HS (2001) Anandamide, but not 2-arachidonoylglycerol, accumulates during in vivo neurodegeneration. J. Neurochem. 78: 1415-1427

19. Hansen HH, Ikonomidou C, Bittigau P, Hansen SH and Hansen HS (2001) Accumulation of the anandamide precursor and other $\mathrm{N}$-acylethanolamine phospholipids in infant rat models of in vivo necrotic and apoptotic neuronal death. J. Neurochem. 76: 39-46

20. Hansen HS, Moesgaard B, Petersen G and Hansen HH (2002) Putative neuroprotective actions of $\mathrm{N}$-acyl-ethanolamines. Pharmacol. Ther. 95: $119-126$

21. van der Stelt M, Veldhuis WB, van Haaften GW, Fezza F, Bisogno T, Bar PR Veldink GA, Vliegenthart JF, Di Marzo V and Nicolay K (2001) Exogenous anandamide protects rat brain against acute neuronal injury in vivo. J. Neurosci. 21: $8765-8771$

22. Szallasi A, Blumberg PM, Annicelli LL, Krause JE and Cortright DN (1999) The cloned rat vanilloid receptor VR1 mediates both R-type binding and C-type calcium response in dorsal root ganglion neurons. Mol. Pharmacol. 56: $581-587$

23. Jerman JC, Brough SJ, Priniha R, Harries MH, Davis JB and Smart D (2000) Characterization using FLIPR of rat vanilloid receptor (rVR1) pharmacology. $\mathrm{Br}$. J. Pharmacol. 130: 916-922

24. Smart D, Jerman JC, Gunthorpe MJ, Brough SJ, Ranson J, Cairns W, Hayes PD, Randall AD and Davis JB (2001) Characterisation using FLIPR of human vanilloid VR1 receptor pharmacology. Eur. J. Pharmacol. 417: 51-58

25. Gatley SJ, Gifford AN, Volkow ND, Lan R and Makriyannis A (1996) 123Ilabeled AM251: a radioiodinated ligand which binds in vivo to mouse brain cannabinoid CB1 receptors. Eur. J. Pharmacol. 307: 331-338

26. Ross RA, Brockie HC, Stevenson LA, Murphy VL, Templeton F, Makriyannis A and Pertwee RG (1999) Agonist-inverse agonist characterization at CB1 and CB2 cannabinoid receptors of L759633, L759656, and AM630. Br. J. Pharmacol. 126: 665-672

27. Ueda $Y$, Katsuta K, Nakanishi $H$ and Yoshida K (1995) Non-competitive NMDA antagonists, FR115427 and MK801, enhance neuronal survival in primary culture. Neurosci. Lett. 185: 107-110

28. Wiley JL, Dewey MA, Jefferson RG, Winckler RL, Bridgen DT, Willoughby KA and Martin BR (2000) Influence of phenylmethylsulfonyl fluoride on anandamide brain levels and pharmacological effects. Life Sci. 67: 1573-1583
29. Fowler CJ, Borjesson M and Tiger G (2000) Differences in the pharmacological properties of rat and chicken brain fatty acid amidohydrolase. Br. J. Pharmacol. 131: 498-504

30. Movsesyan VA, Yakovlev AG, Dabaghyan EA, Stoica BA and Faden AI (2002) Ceramide induces neuronal apoptosis through the caspase-9/caspase-3 pathway. Biochem. Biophys. Res. Commun. 299: 201-207

31. Eldadah BA, Yakovlev AG and Faden AI (1997) The role of CED-3-related cysteine proteases in apoptosis of cerebellar granule cells. J. Neurosci. 17: 6105-6113

32. Nakajima M, Kashiwagi K, Ohta J, Furukawa S, Hayashi K, Kawashima T and Hayashi Y (1994) Etoposide induces programmed death in neurons cultured from the fetal rat central nervous system. Brain Res. 641: 350-352

33. Garcia-Calvo M, Peterson EP, Leiting B, Ruel R, Nicholson DW and Thornberry NA (1998) Inhibition of human caspases by peptide-based and macromolecular inhibitors. J. Biol. Chem. 273: 32608-32613

34. Janicke RU, Sprengart ML, Wati MR and Porter AG (1998) Caspase-3 is required for DNA fragmentation and morphological changes associated with apoptosis. J. Biol. Chem. 273: 9357-9360

35. Yang XH, Sladek TL, Liu X, Butler BR, Froelich CJ and Thor AD (2001) Reconstitution of caspase 3 sensitizes MCF-7 breast cancer cells to doxorubicin- and etoposide-induced apoptosis. Cancer Res. 61: 348-354

36. Pike BR, Zhao X, Newcomb JK, Posmantur RM, Wang KK and Hayes RL (1998) Regional calpain and caspase-3 proteolysis of alpha-spectrin after traumatic brain injury. Neuroreport 9: 2437-2442

37. Blomgren K, Zhu C, Wang X, Karlsson JO, Leverin AL, Bahr BA, Mallard C and Hagberg $H$ (2001) Synergistic activation of caspase-3 by m-calpain after neonatal hypoxia-ischemia: a mechanism of pathological apoptosis? J. Biol. Chem. 276: 10191-10198

38. Brown TL, Patil S, Cianci CD, Morrow JS and Howe PH (1999) Transforming growth factor beta induces caspase 3-independent cleavage of alphall-spectrin (alpha-fodrin) coincident with apoptosis. J. Biol. Chem. 274: 23256-23262

39. See V and Loeffler JP (2001) Oxidative stress induces neuronal death by recruiting a protease and phosphatase-gated mechanism. J. Biol. Chem. 276: 35049-35059

40. Chan SL and Mattson MP (1999) Caspase and calpain substrates: roles in synaptic plasticity and cell death. J. Neurosci. Res. 58: 167-190

41. Dutta S, Chiu YC, Probert AW and Wang KK (2002) Selective release of calpain produced alphall-spectrin (alpha-fodrin) breakdown products by acute neuronal cell death. Biol. Chem. 383: 785-791

42. Wang KK, Posmantur R, Nath R, McGinnis K, Whitton M, Talanian RV, Glantz SB and Morrow JS (1998) Simultaneous degradation of alphall- and betall-spectrin by caspase 3 (CPP32) in apoptotic cells. J. Biol. Chem. 273: 22490-22497

43. Sato K, Saito $Y$ and Kawashima S (1995) Identification and characterization of membrane-bound calpains in clathrin-coated vesicles from bovine brain. Eur. J. Biochem. 230: 25-31

44. Sprague J, Harrison C, Rowbotham DJ, Smart D and Lambert DG (2001) Temperature-dependent activation of recombinant rat vanilloid VR1 receptors expressed in HEK293 cells by capsaicin and anandamide. Eur. J. Pharmacol. 423: $121-125$

45. De Petrocellis L, Bisogno T, Maccarrone M, Davis JB, Finazzi-Agro A and Di Marzo V (2001) The activity of anandamide at vanilloid VR1 receptors requires facilitated transport across the cell membrane and is limited by intracellular metabolism. J. Biol. Chem. 276: 12856-12863

46. Panikashvili D, Simeonidou C, Ben-Shabat S, Hanus L, Breuer A, Mechoulam $R$ and Shohami $E$ (2001) An endogenous cannabinoid (2-AG) is neuroprotective after brain injury. Nature 413: 527-531

47. Sinor AD, Irvin SM and Greenberg DA (2000) Endocannabinoids protect cerebral cortical neurons from in vitro ischemia in rats. Neurosci. Lett. 278: $157-160$

48. Jerman JC, Gray J, Brough SJ, Ooi L, Owen D, Davis JB and Smart D (2002) Comparison of effects of anandamide at recombinant and endogenous rat vanilloid receptors. Br. J. Anaesth. 89: 882-887

49. Sarker KP and Maruyama I (2003) Anandamide induces cell death independently of cannabinoid receptors or vanilloid receptor 1: possible involvement of lipid rafts. Cell Mol. Life Sci. 60: 1200-1208

50. Li P, Nijhawan D, Budihardjo I, Srinivasula SM, Ahmad M, Alnemri ES and Wanga X (1997) Cytochrome $C$ and dATP-dependent formation of Apaf-1/ caspase-9 complex initiates an apoptotic protease cascade. Cell 91: 479-489 
51. Noshita N, Lewen A, Sugawara T and Chan PH (2001) Evidence of phosphorylation of Akt and neuronal survival after transient focal cerebral ischemia in mice. J. Cereb. Blood Flow Metab. 21: 1442-1450

52. Dubois-Dauphin M, Pfister Y, Vallet PG and Savioz A (2001) Prevention of apoptotic neuronal death by controlling procaspases?. A point of view. Brain Res. Rev. 36: 196-203

53. Yakovlev AG, Ota K, Wang G, Movsesyan V, Bao WL, Yoshihara K and Faden Al (2001) Differential expression of apoptotic protease-activating factor-1 and caspase-3 genes and susceptibility to apoptosis during brain development and after traumatic brain injury. J. Neurosci. 21: 7439-7446

54. Zhou H, Li XM, Meinkoth J and Pittman RN (2000) Akt regulates cell survival and apoptosis at a postmitochondrial level. J. Cell Biol. 151: 483-494

55. Deshmukh M and Johnson Jr. EM (1998) Evidence of a novel event during neuronal death: development of competence-to-die in response to cytoplasmic cytochrome $c$ [see comments]. Neuron 21: 695-705

56. Glassford A, Lee JE, Xu L and Giffard RG (2002) Caspase inhibitors reduce the apoptotic but not necrotic component of kainate injury in primary murine cortical neuronal cultures. Neurol. Res. 24: 796-800

57. Gil-Parrado S, Fernandez-Montalvan A, Assfalg-Machleidt I, Popp O, Bestvater F, Holloschi A, Knoch TA, Auerswald EA, Welsh K, Reed JC, Fritz H, FuentesPrior P, Spiess E, Salvesen GS and Machleidt W (2002) lonomycin-activated calpain triggers apoptosis. A probable role for Bcl-2 family members. J. Biol. Chem. 277: 27217-27226
58. Movsesyan VA, O'Leary DM, Fan L, Bao W, Mullins PG, Knoblach SM and Faden Al (2001) mGluR5 antagonists 2-methyl-6-(phenylethynyl)-pyridine and (E)-2-methyl- 6-(2-phenylethenyl)-pyridine reduce traumatic neuronal injury in vitro and in vivo by antagonizing $N$-methyl-D-aspartate receptors. J. Pharmacol. Exp. Ther. 296: 41-47

59. Toman R, Movsesyan V, Murthy S, Milstien S, Spiegel S and Faden A (2002) Ceramide-induced cell death in primary neuronal cultures: upregulation of ceramide levels during neuronal apoptosis. J. Neurosci. Res. 68: 323-330

60. Pan G, O'Rourke K and Dixit VM (1998) Caspase-9, Bcl-XL, and Apaf-1 form a ternary complex. J. Biol. Chem. 273: 5841-5845

61. Sinensky MC, Leiser AL and Babich H (1995) Oxidative stress aspects of the cytotoxicity of carbamide peroxide: in vitro studies. Toxicol. Lett. 75: 101-109

62. Gomez C, Reiriz J, Pique M, Gil J, Ferrer I and Ambrosio S (2001) Low concentrations of 1-methyl-4-phenylpyridinium ion induce caspase- mediated apoptosis in human SH-SY5Y neuroblastoma cells. J. Neurosci. Res. 63: $421-428$

63. Waterhouse NJ, Goldstein JC, Kluck RM, Newmeyer DD and Green DR (2001) The (Holey) study of mitochondria in apoptosis. Methods Cell Biol. 66: 365-391

64. Tovey SC, Dyer JL, Godfrey RE, Khan SZ, Bilmen JG, Mezna M and Michelangeli $F$ (2000) Subtype identification and functional properties of inositol 1,4, 5- trisphosphate receptors in heart and aorta. Pharmacol. Res. 42 : $581-590$ 